\title{
Chapter 11 \\ What Counts as World Class? Global \\ University Rankings and Shifts \\ in Institutional Strategies
}

\author{
Tero Erkkilä and Ossi Piironen
}

\begin{abstract}
Global university rankings have emerged as a benchmark of institutional success, setting standards for higher education policymaking and institutional practices. Nevertheless, only a marginal share of higher education institutions (HEI) are in a realistic position to be ranked as a 'world-class' institutions. In the European context, the global rankings have been used to highlight a performance gap between European and North American institutions. Here the focus has been on the HEIs in the top-100 positions, causing concerns over European higher education. This has also become a marker of world-class university. We analyze the strategies of 27 Northern European universities in different tiers to learn how they have adjusted to the reality of ranking. We conclude that the references to global rankings have increased between 2014 and 2018. At the same time, the references to rankings have become more implicit in nature. Nevertheless, we find that the discourse of global comparison and excellence has become more common in the strategies. There are also emerging references to the regional role of universities, which are apparent in the strategies of universities that are clearly outside the top-100 ranked institutions. However, this is also a reflection of the discourse of world-class university.
\end{abstract}

\section{Introduction}

At present, academic institutions' strategies rather universally aim at world-class research and education. Global university rankings have emerged as a benchmark of institutional success, setting standards for higher education policymaking and institutional practices. Nevertheless, only a marginal share of higher education

\author{
T. Erkkilä $(\bowtie)$ \\ Political Science, University of Helsinki, Helsinki, Finland \\ e-mail: Tero.Erkkila@helsinki.fi \\ O. Piironen \\ Ministry for Foreign Affairs, Government of Finland, Helsinki, Finland
}

(C) The Author(s) 2020

S. Rider et al. (eds.), World Class Universities, Evaluating Education:

Normative Systems and Institutional Practices,

https://doi.org/10.1007/978-981-15-7598-3_11 
institutions (HEI) are in a realistic position to be ranked as a 'world-class' institution. The rankings also have regional implications, as they have been used to highlight a performance gap between European and North American institutions. In the European context, the focus has been on the HEIs in the top- 100 positions, causing concerns over European higher education. This has also become a marker of worldclass university.

In this article, we analyze the strategies of 27 Northern European universities to learn how they have adjusted to the reality of ranking: how are the international rankings present in universities institutional strategies, and are there differences in approach between universities in different tiers of academic achievement measured by global league tables? Based on our empirical analysis, we conclude that the rankings game is still first and foremost played by those who can use the scores to demonstrate their success or willingness to improve their current position.

However, there seems to be increasing awareness of the pitfalls for trying to set institutional goals based on rankings, let alone gaming them. Moreover, the references to global rankings become more implicit between 2014 and 2018, our two points of analysis. At the same time, we find that the discourse of global comparison and excellence has become more common in the strategies. There are also emerging references to the regional role of universities, which are apparent in the strategies of universities that are clearly outside the top-100 ranked institutions. We nevertheless perceive this as a reflection of the discourse of world-class university, now also involving institutions that are not credibly able to participate in the race.

\section{Transnational Higher Education: Global University Rankings as a Policy Discourse}

Higher education policy experts and scholars have closely followed global university rankings (Cheng and Liu 2006, 2007; Hazelkorn 2008; Marginson and van der Wende 2007; Salmi 2009). The academic research on global rankings has largely focused on their methodology (Dehon et al. 2009a, b; Shin et al. 2011). Scholars have also identified the impacts of rankings on higher education institutions and policies (Erkkilä 2013; Hazelkorn 2011; Kehm and Stensaker 2009; Münch 2013). Furthermore, the university rankings have been linked to the global governance of knowledge (King 2010; Shin and Kehm 2012).

As higher education becomes the subject of global comparisons as a result of global rankings, reforms on the national level are increasingly informed by these transnational policy scripts that provide blueprints for policy actions (Schofer and Meyer 2005). Institutional research has drawn attention to discourse in the communication of new policy ideas (Schmidt 2010). The university rankings have come to guide national efforts to reform higher education. This is particularly visible in Europe and Asia (Deem et al. 2008; Erkkilä and Piironen 2013b). In many instances, the impact of rankings is indirect, serving as a new reference point in the reform debates and, as such, used as objective information to back up certain policy positions (Dakowska 2013; Mok 2007; Reinalda and Kulesza 2006). 
The discourses on rankings and global higher education also concern the notion of resistance. The global rankings are said to resemble Foucauldian governance at a distance (cf. Miller and Rose 1990), where the reflexivity over the rankings is a mechanism for institutional change - the actors feel obliged to adhere to a perceived norm without questioning it. In a similar fashion, the rankings can be seen to form a Weberian 'iron cage' (Erkkilä and Piironen 2009), where the calculative means of bureaucratic observation leads to instrumental rationality that leaves no room for politics and ethics (value rationality). Similarly, the convergence of institutional forms through diffusion is often seen to come through isomorphism (DiMaggio and Powell 1983; Schofer and Meyer 2005). The global university rankings have come to portray academic activity as global competition, idealizing American top institutions as a model to follow. The political image of competition and the related 'American model' are seldom questioned.

\section{Global University Rankings and 'European Higher Education'}

The rankings have caused a particular policy concern in Europe due to the relatively poor ranking of European universities and Europe's diminished role in the global economy. What is interesting about this development is the role of the European Commission, which has been active in drafting policies for 'European higher education', a policy domain that traditionally has not come within the EU's ambit. These initiatives have been closely linked to the EU's economic ambitions. Europe also provides an interesting case for analyzing the perceptions of global university rankings, since they stand in contrast to longstanding academic traditions in Europe (de Ridder-Symoens 2003a, b; Rüegg 2004, 2010).

Global university rankings can be seen as a case of transnational policy discourse on higher education that contains several sub-discourses. Previous analyses have linked the rankings to a specific discourse on economic competitiveness that now covers academic competition and the pursuit of becoming a 'world class university' (Shin and Kehm 2012). The rankings are also part of the EU's 'modernization' agenda in higher education (see the following section), which somewhat paradoxically claims to strive for both 'excellence' and 'diversity' at the same time, even though these qualities are in apparent conflict. Global rankings are also part of a discourse on academic 'quality', serving as evaluative tools.

On a national level, there are various university reforms that include the rankings as a point of reference for certain policy measures. As is typical for transnational policy discourses (Schmidt 2006), there are differences in the domestic discourses about rankings, despite general recurring themes that are part of reform agenda. The way policy problems are framed has power implications, as it often initiates the discussion and blocks other perceptions from entering the agenda (Bacchi 1999). The rankings have helped to frame higher education as an issue of economic competition requiring action at the EU level. On a national level, policy actors have also referred to rankings when promoting reform agendas. 
Global university rankings create a political imaginary of competition that has policy implications; the rankings idealize certain models, advancing ideas involving privatization, accountability, (financial) autonomy, and excellence initiatives. Moreover, the rankings have geographical implications, making it possible to identify 'European' policy concerns and leading to attempts to increase EU level regulation of higher education that has previously remained under national control.

The rankings make comparisons seemingly facile. European HEIs are now increasingly being compared to the American and Asian universities. Within Europe, the rankings have shown clear differences between countries and systems, such as the differences between the British, German and French universities, where the top institutions in the UK fare significantly better. One critique of this policy discourse has been that it often overlooks the general institutional context in which HEIs function in a given country.

Moreover, the composition of global university rankings differs in comparison to other global indicators as they rank institutions and not national systems. For example, the OECD PISA, perhaps the best know indicator of education, ranks national systems (and not individual schools), elevating countries such as Finland that have traditionally had an egalitarian approach to primary education, meaning that there are no elite schools. The logic of university rankings is the opposite, as they elevate top institutions but do not consider the systemic context where these exist. Nevertheless, the global university rankings are being used for systemic comparisons, most notably in Europe.

Despite the above limitations, the global university rankings have direct policy implications. They are increasingly being referred to as a motivation for adopting new higher education policies. Often in the background is the hope for economic gains through higher education as an element of innovation. The poor ranking of European universities was framed as a 'policy problem' in 2005 (Bacchi 1999), when the European Commission cites the Shanghai and THE Rankings indicating that European universities fare poorly in global comparisons vis-à-vis universities in the US and Asia (European Commission 2005b). At about the same time, a good ranking in the global assessments came to be coupled with the notion of economic competitiveness (European Commission 2005a).

The rankings also constitute a remedy for the ailing state of higher education in Europe. Since the mid-2000s, the policy documents of the European Commission have named 'accountability' as a driver for 'modernization' of higher education in Europe (European Commission 2005b, 2006), where the higher education institutions now are accountable 'to society' (European Commission 2005b, p. 9), which means HEIs are assigned responsibility for economic growth. The rankings are both indicators of the problems in higher education in Europe, and tools for attaining desired goals, including those set out in the Lisbon Strategy (European Commission 2008, 2009).

Notably, the European Commission here denounces an idea of a single model for excellence in higher education and calls instead for 'diversity': “[T]oo few European higher education institutions are recognised as world class in the current, researchoriented global university rankings. [...] There is no single excellence model: 
Europe needs a wide diversity of higher education institutions, and each must pursue excellence in line with its mission and strategic priorities." (European Commission 2011, pp. 2-3). But how does diversity match with quantification and the policy problem of too few universities being recognized as 'world class'? In the following, we explore how the international rankings are present in European universities institutional strategies and what differences there are between universities in different tiers of academic achievement measured by global league tables. We first briefly outline certain issues of global university rankings that are relevant for our findings.

\section{Rankings, Models and Institutions of Higher Education}

Increasing number of higher education institutions have, in a way or another, internalized into their strategic planning the performance-oriented vision of academic achievement that the rankings carry within their methodology and comparative format. Ellen Hazelkorn's research (2007, 2009, 2011), covering 41 countries and 202 institutions, indicates that rankings are well known to institutional managers, and that institutions commonly react to rankings by adaptation: for example, $63 \%$ of institutions in her sample had taken strategic, organizational, managerial or academic action in response to international rankings (Hazelkorn 2011, p. 96). Even more importantly from our perspective, is the finding that over eight out of ten wanted to improve their position in international rankings (Ibid., p. 86). In important respects, the findings of William Locke et al. (2008, especially chapter 4), looking at British institutions $(\mathrm{n}=91)$, paint a rather similar picture.

In conjunction with empirical observations, we were troubled by the growing consensus that the international rankings more than anything else uphold a very particular ideal of institutional success. We (see Erkkilä and Piironen 2013a), and, it would seem, many others (Pelkonen and Teräväinen-Litardo 2013, p. 63; Gornitzka 2013, p. 82; Kauppi 2013, pp. 168-169; Münch 2013; see also Teichler 2011, pp. 64-64; and Morphew and Swanson 2011, p. 187; Olsen and Maassen 2007, pp. 13-17) are inclined to think that the rankings have played their part in raising the U.S. Ivy League research university to a global model. This model has served as an incentive for reforms on national and institutional levels all around Europe with scarce understanding that the Ivy League only marginally represents the totality of the U.S. educational system(s) (Cohen and Kisker 2010).

According to Cohen and Kisker (2010, pp. 435-442), the U.S. system of higher education comprises more than 4000 non-profit institutions, most of which represent lower tiers of academic achievement in terms of research, awarded degrees and average length of enrolment. In 2006, doctorates were awarded by 622 institutions, but half of the PhD's were concentrated in only 60 leading research universities (ibid. p. 453). In addition to the traditional higher education system- "the 4300 nonprofit, degree-granting, public and independent community colleges, four-year colleges, and universities"- “a parallel system of postsecondary for-profit 
proprietary schools has grown", some 900 institutions granting degrees similar in the nonprofit sector (ibid p. 456). Nevertheless, the top institutions-being exceptional in terms of wealth and institutional history, but diverging in their size, organization and financial arrangements-are seen as objects of emulation by thousands of less wealthy institutions both inside and outside the U.S.

Focusing directly on rankings, it is problematic that reaching the "top-tier" is virtually impossible for most research institutions, and even more so in a situation where league tables themselves reinforce the prestige and standing of the leaders. Many scholars have observed that—and sought to explain how-rankings constitute a self-fulfilling prophesy by reinforcing the position of top-ranked universities (Kehm 2013; Münch 2013; Nixon 2013; Locke 2011, p. 223; Teichler 2011). According to Morphew and Swanson (2011, p. 191), it is extremely hard to lose institutional reputation once constructed: 'Similarly, the monolithic nature of being an "elite" institution is impressive. For example, in US News, the dominant United States ranking guide, only 29 schools occupied the top 25 spots between 1988 and 1998, and 20 institutions never fell out of the top 25.'

Despite the fact that it is extremely difficult for second-tier research universities to break into the elite class, $70 \%$ of the participating institutions in Hazelkorn's (2011, p. 86) survey expressed their wish to be counted in top $10 \%$ nationally, and $70 \%$ of the respondents in the top 25\% internationally. There is an obvious discrepancy between institutional aspirations and the real possibilities to break through: only a marginal share of HE institutions are in a realistic position to rank among the best 200 institutions.

Most university rankings only cover some 500-700 institutions, meaning that most of the world's 18,000 academic institutions are left out. Effectively, the rankings come to focus on a limited number of higher education institutions, providing a very exclusive and unrepresentative perspective on what the world of higher education is. A recent comparison of the 2013 results of ARWU, THES and QS shows that they mostly contain North American, European and Asian universities (Erkkilä 2016). In the ARWU ranking, there is a clear predominance of North American and European universities. Among the top 20 ranked universities, there are 17 institutions from North America and 3 from Europe. The North American lead continues in the top 50 and top 100 categories of the rankings. However, the more institutions one includes in the ranking, the less pronounced this standing becomes. When we compare the top 500 ranked institutions, there are more European Universities (200) than North American (173). The THE ranking (2013-2014) provides a similar picture. In the top 20, there are 16 institutions from North America and 4 European universities. North America's lead is clear in the top 100, but already among the top 200 there are more European than North American institutions. In the top-400ranked institutions, there are 128 North American and 181 European universities, similar to the ARWU. The QS ranking (2013-2014) covers 700 institutions, 162 of which are located in North America and which dominate the top 100 positions. Among the 700 institutions compared, there are 282 European institutions listed. Interestingly, there are also 165 institutions from Asia, slightly more than those from North America. In short, when considering the top-700 positions there are 
almost twice as many institutions from Europe as there are from North America (Erkkilä 2016).

Against this background, it is peculiar that the readings of the rankings in the European context tend to focus on the top 100, with little attention to the overall number of universities ranked. This underlines that we are indeed comparing individual institutions and not higher education systems. Moreover, it is highly questionable whether competition in terms of league table standings can contribute to academic knowledge production (see Münch 2013). But the initial framing of the policy problem (Bacchi 1999) of European higher education has come to dominate the debate on the future of higher education.

In our opinion, the way higher education is seen today, partially thanks to the competitive logic of institutional ranking, is overly individualizing (Erkkilä and Piironen 2015). Scientific progress and academic achievement are now seen as aggregations of institutional and individual performance. The systemic outlook on higher education has been weakened by policies that stress organizational autonomy and accountability. Moreover, there is increasing evidence that institutional actors have internalized their role as separate entities or 'managerial competitors' instead of 'academic competitors', to borrow Münch's (2013, pp. 210-214) conclusions and terminology. The individualizing tendencies undoubtedly foster institutional competition between mid- and lower-tier institutions in recruitment of students and staff, attraction of funding and production of research outputs. This is, of course, just what the European policy-makers have intended (see e.g. Olsen and Maassen 2007, pp. 3-22). The problem is that there is no real evidence supporting the belief that increased managerial competition between academic organizations would be beneficial—overall—in terms of scholarly achievement, societal welfare or organizational efficiency (ibid., pp. 13-17).

Based on previous studies (Hazelkorn 2007, 2009, 2011; Locke 2011; Locke et al. 2008), we know that rankings do affect institutions' strategic work, albeit in varying ways, often indirectly and unconsciously, though not uniformly: institutional responses may differ according to ranking position. We see that institutional rankings generally maintain an atomist imaginary, projecting higher education systems as aggregations of unitary actors (i.e. institutions) competing against each other. Moreover, we maintain that most prominent international university rankings are built on an ideal-type construction of a market-oriented, successful U.S. research institution - such as Harvard, Stanford, or M.I.T. - that is now inappropriately projected as a universal model to be imitated by all types of academic institutions all around the globe. This perception seems to be at the heart of the policy problem of 'European higher education'.

In short, we are highly critical towards the rankings for their tendency to maintain a very particular model of the successful research university, based on a onesize-fits-all principle irrespective of contextual variable factors, as well as their tendency to individualize the higher education landscape in constructing a vision of universities as competitive managerial units, composed of an aggregation of unsociable individuals. In the following, we analyze the strategies of European universities to learn how they have accommodated to the reality of ranking: how do 
universities in different tiers of "excellence" react to pressures to improve their ranking positions - or even to get noticed? Moreover, we are interested in the universities' positioning in spatial terms - to what extent are they engaged in the global race for excellence, or, if they rather have a more regional focus, whether this would appear to be an alternative to the global models? We are particularly interested in the top-100 as a marker of excellence, reflected in the case selection of our analysis.

\section{Global University Rankings and HEIs Strategies}

Universities' strategy work—-strategic planning and strategic management-fulfills several demands, both internal and external. The most robust demand comes from governments still influenced by the managerial programme: the new autonomous universities must be capable of long-term planning, set objectives and prioritiesdefine ends and means - and report back on their performance (Hughes 2003). In this case, the function is managerial: academic institutions must work as a unity towards a common purpose, and the leadership of the institutions must be emancipated to have the means of steering their ships according to the agreed upon coordinates. The imperative to guarantee both control and results lends not only legitimacy to institutional leadership but also provides them with an effective management tool.

The second important function of strategy work is communicative: strategic plans are intended to fashion impressions and transfer information. Here rankings are seen as strategic resources for bolstering competitive advantage, not simply as strategic objectives or evaluative instruments for management. Internally, strategies can be used to motivate the faculty and students. Externally, they may be used to buttress institutional reputation and gain visibility, which is hoped to support recruitment of students and staff, to increase awareness in various stakeholder groups, and especially to help in attracting potential funders and cooperative partners. According to Morphew and Swanson (2011), rankings provide an efficient strategy for those already at the top. If rankings were seen purely as strategic management tools, we would expect to see references more evenly distributed between top- and lower-tier universities' strategies. If the function were exclusively communicative in nature, we would expect to find celebratory references in the strategies of institutions that perform well while they would be omitted or challenged in the strategies of the less successful.

\section{Case Selection}

Our inquiry aims to shed more light on whether (and how) global rankings are present in universities' strategic planning: how are the rankings represented in 27 Northern European universities' primary strategy documents? And how is the predominant focus on the top-100 as a marker of excellence reflected in their reference 
to rankings? Moreover, we are interested in whether (and how) institutional ranking position is connected to the way strategies treat rankings: is there a difference in how references of rankings are embedded in the strategy documents of our sample institutions in terms of their ranking performance? While our analysis covers representations of national and international league tables alike, the focus is clearly on the latter. We have analyzed the strategies of universities over two points in time, in 2013 and again in 2018, allowing us to assess changes in the strategy language over time. We have identified references to the regional role of the universities as an emergent theme in 2018.

In the analysis, we observed the following: ${ }^{1}$

1. References to national university rankings: explicitly yes/implicitly yes/none

2. References to international university rankings: explicitly yes/implicitly yes/none

3. Kinds of implicit references to international rankings: how is comparative rhetoric brought in? (e.g. "internationally leading in...", "world-class", "worldleading", etc.)

4. How are international rankings represented in general: in positive, neutral or negative light?

5. How is the institution's current international ranking position dealt with?

(a) lauded and used as evidence of excellence

(b) neutrally stated

(c) its meaning (or that of the ranking as a whole) played down or disparaged

(d) not mentioned at all

6. Are there references to the regional role of the university?

We explore how rankings and ranking positions represent themselves in the strategies of 27 academic institutions' strategic orientation and whether the ranking position and cultural/political/geographical context is associated with the type of treatment strategy documents give to university rankings. The three countries or 'country blocks' examined are all from Northern Europe, representing three differing higher education landscapes (in terms of culture, legislation, funding mechanisms, function and societal expectations):

- the British,

- the German,

- the Nordic (consisting of Norwegian, Swedish and Finnish universities)

Along with the country-based classification, we selected universities in three "performance categories", using the 2012 Academic Ranking of World Universities (ARWU, the "Shanghai ranking") as a reference:

- close to top universities (50-150)

\footnotetext{
${ }^{1}$ The framework's guiding questions were constructed in phases taking note to our premises and the example set by Hazelkorn (2011) and Locke et al. (2008); it was then elaborated after the first reading of strategy papers to ascertain its relevancy from the data's perspective (Table 11.1).
} 
- barely listed universities (401-500)

- unlisted universities.

We explicitly excluded the top-50 institutions (on the ARWU ranking), since we presume that these elite universities in many ways fit the model that ranking methodology proxies. We are more interested in the strategies of those institutions close to the top: do the institutions holding the positions from 50 to 150 give the impression that they have a real chance to break into the elite class, and how motivated are they in attempting to do so? And are there differences between the group of the barely listed institutions (ranked between 401 and 500) and those who have not made it to the list? We see references to rankings and especially target setting in terms of rankings in these lower-tier groups as a potential means for the logic of competition to enter university strategies and academic practice.

Our cases are drawn from the European University Association (EUA) member database and its 737 Individual Full Members from over 40 countries. ${ }^{2}$ We look at strategies of 27 Northern European universities with equal representation of three country blocks and three performance categories (as described above). We use several pre-determined rules to diminish the initial 737 population to 27 cases-effectively avoiding selecting institutions according to the contents of their strategies. Use of the EUA member database is itself restrictive in the sense that it excludes higher education institutions primarily or exclusively oriented toward education. We further limit the number of institutions by focusing on three country blocks, thus limiting the geographical/cultural variation. For sake of comparability, we excluded from our sample also: ${ }^{3}$

- institutions providing only distance education

- monodisciplinary institutions: an institution is included if it is clearly engaged with more than one field of science (Technology/Engineering, Medicine/Health, Humanities, Social Sciences, Natural Sciences, Law, Arts, Business/Economics and Education).

- institutions that do not offer the full range of degrees (BA, MA, $\mathrm{PhD}$ )

Table 11.1 shows the selected universities classified according to the country block and performance category. As our primary data, we used the key strategic documents of each of the institutions. As a first observation of our empirical

\footnotetext{
${ }^{2} \mathrm{See}$ http://www.eua.be/eua-membership-and-services/Home/members-directory.aspx (accessed 6th September 2013).

${ }^{3}$ Together with the decision to use of the EUA database these rules guarantee that sample institutions have both research and education functions: for example, the German and Finnish universities of applied sciences are excluded, which is justified because it is evident that international university rankings do not feature in these institutions' strategies. Some additional criteria of exclusion were applied if there were more than three institutions left in an analytical group defined by country group and performance category, namely cases showing considerable discrepancy between the ARWU ranking 2012 and other prominent university rankings, and, as a last resort, if there were still more than three cases per category, the final criteria excluded the smallest institutions (least students).
} 
Table 11.1 Selected universities by ARWU performance group $(1=50-150 ; 2=401-500$; $3=$ unlisted) and country block

\begin{tabular}{l|l|l|l}
\hline & UK $^{\mathrm{a}}$ & German & Nordic \\
\hline \multirow{2}{*}{1} & University of Nottingham & Technical University Munich & Uppsala University (SWE) \\
& University of Birmingham & LMU Munich & Stockholm University (SWE) \\
& University of Liverpool & Heidelberg University & Lund University (SWE) \\
\hline 2 & University of Essex & Friedrich Schiller University Jena & University of Eastern Finland \\
& University of Surrey & University of Duisburg-Essen & University of Jyväskylä (FI) \\
& Swansea University & University of Hannover & University of Troms $\varnothing$ (NOR) \\
\hline \multirow{2}{*}{3} & Anglia Ruskin & Saarland University & Linnaeus University (SWE) \\
& Sheffield Hallam & Technical University Dortmund & University of Luleå (SWE) \\
& Central Lancashire & University of Kassel & Malmö University (SWE) \\
\hline
\end{tabular}

${ }^{a}$ All of the sample institutions in the UK block are from England except for the Welsh Swansea University. It is a pure coincidence that Scottish and Northern Irish institutions were excluded in the selection process

exercise, it is worth noting that all of the 27 institutions did have a strategic plan of some sort. These documents, despite a variation of titles-'strategy', 'strategic plan', and 'corporate plan' - and despite the length varying from three to tens of pages, were easy to identify as functionally corresponding. We analyze the data in the original language, but direct quotations are presented from the English-language versions, where available. ${ }^{4}$

The strategy documents had been issued at varied times, and covered a wide range of time periods. We did not systematically analyze the content of institutions' web pages or other official documents (such as performance contracts or financial reports), although our general impression is that references to international rankings are more often and more visibly used as tools for marketing and advertising in the institutions' webpages than in the official strategy papers. Nevertheless, we see that strategies as more often directly tied to corporate management process are of more analytical value.

\section{References to National and International Rankings}

In the first instance, we examined whether the strategies withheld references to national and international university rankings: our focus is mainly on measurements related to overall academic (or research) performance. We exclude from the analysis references to specific indicators, for example, employability after graduation, student feedback or environmental sustainability. An explicit reference is the use of the word 'ranking', 'ranking position' or 'league table'; or a specific measurement (Shanghai, QS, THES, RAE/REF, etc.). We also counted as explicit references mentions of institutions' current/targeted ranking positions. An implicit reference was an indirect utterance that wanted the existence of comparative frameworks and

\footnotetext{
${ }^{4}$ As method, we applied conventional qualitative content analysis.
} 
information (“...to strengthen its position as a world leading university"). The emphasis, however, is on explicit references to international rankings.

On the whole, our analysis indicates a rather weak association between the performance category and references to national rankings: institutions in higher ranking positions have only slightly more often explicit references to national rankings than their less prestigious counterparts. The British block, most likely due to the strong influence of RAE/REF exercise in the UK, behaved uniformly: national rankings were mentioned explicitly in all strategies except for the University of Surrey, which only makes an implicit reference in 2014 ("a leading national and international university"). Anglia Ruskin and Sheffield Hallam make explicit reference to national rankings in 2014, but make no mention of them when analyzed in 2018.

In the Nordic group, the association between table standing and incorporation of rankings discourse into institutional strategy was more as expected: no referencesexplicit or implicit - to national rankings were made in the strategies of the three unlisted universities in 2014, and only the University of Malmö makes an implicit reference to them. Implicit references were found in half of the strategies representing the two higher performance categories in 2014; the University of Eastern Finland, for example, wanting to be "among the three most important universities in Finland". In 2018, of the ARWU ranked institutions, only the University of Stockholm makes an implicit reference to national raking.

In the German cases, references to national rankings (especially to the CHE ranking) concentrated on the mid-tier institutions in 2014, all three making explicit references to them, while non-references dominated other categories. In 2018, however, there are no references to national rankings, except for Friedrich Schiller University in Jena. This "silence" is interesting, reflecting also the national criticism that the CHE ranking has faced, with institutions even boycotting it in recent years.

The references to international league tables are firmly tied to institutional ranking positions (Table 11.2). While almost all first-tier institutions (except for the German LMU Munich) referred to global rankings-7 explicitly, 4 implicitly_in 2014, only one of the unlisted institutions did so too. But even here the tone was different. While the top-performers were often more specific in their goal settingfor example, the "key ambition" of the Liverpool University proclaiming its ambition to "be positioned in the top 75 of a recognized international league table"-the University of Central Lancashire as the unlisted outlier was merely keen to advertise its recent entry in the 601+ category on the QS ranking. (By 2013, UClan had fallen to the 701+ category.) Perhaps because of the lack of any meaningful national rankings such as those in the UK and Germany, the strategies of Nordic mid-tier universities included references to international rankings, unlike their British and two of their German counterparts.

In 2018, there are only six universities in our sample of 27 that do not refer to global rankings, while there were 13 such cases in 2014. Interestingly, in 2018 the references to global rankings are more implicit, most notably in the UK and German institutions ranking 50-150 in ARWU. In fact, LMU Munich and Heidelberg do not mention rankings at all. Several universities that made explicit reference to their rankings in 2014 now only make only an implicit reference. Only two universities 
11 What Counts as World Class? Global University Rankings and Shifts...

Table 11.2 References to international rankings in 2014 and 2018

\begin{tabular}{|c|c|c|c|c|}
\hline & $\begin{array}{l}\text { Country } \\
\text { Block }\end{array}$ & $\begin{array}{l}\text { Performance } \\
\text { Group }\end{array}$ & $\begin{array}{l}\text { Reference to global } \\
\text { rankings } 2014(\mathrm{No} / \\
\text { Implicit/Explicit) }\end{array}$ & $\begin{array}{l}\text { Reference to global } \\
\text { rankings } 2018(\mathrm{No} / \\
\text { Implicit/Explicit) }\end{array}$ \\
\hline $\begin{array}{l}\text { University of } \\
\text { Nottingham }\end{array}$ & UK & 1 & Explicit & Implicit \\
\hline $\begin{array}{l}\text { University of } \\
\text { Birmingham }\end{array}$ & UK & 1 & Explicit & Implicit \\
\hline $\begin{array}{l}\text { University of } \\
\text { Liverpool }\end{array}$ & UK & 1 & Explicit & Explicit \\
\hline $\begin{array}{l}\text { University of } \\
\text { Essex }\end{array}$ & UK & 2 & Implicit & Implicit \\
\hline $\begin{array}{l}\text { University of } \\
\text { Surrey }\end{array}$ & UK & 2 & Implicit & Explicit \\
\hline $\begin{array}{l}\text { Swansea } \\
\text { University }\end{array}$ & UK & 2 & No & Explicit \\
\hline Anglia Ruskin & UK & 3 & No & Implicit \\
\hline Sheffield Hallam & UK & 3 & No & Implicit \\
\hline $\begin{array}{l}\text { Central } \\
\text { Lancashire }\end{array}$ & UK & 3 & Explicit & Implicit \\
\hline $\begin{array}{l}\text { Uppsala } \\
\text { University }\end{array}$ & Nordic & 1 & Implicit & Explicit \\
\hline $\begin{array}{l}\text { Stockholm } \\
\text { University }\end{array}$ & Nordic & 1 & Explicit & Explicit \\
\hline Lund University & Nordic & 1 & Implicit & Implicit \\
\hline $\begin{array}{l}\text { University of } \\
\text { Eastern Finland }\end{array}$ & Nordic & 2 & Explicit & Explicit \\
\hline $\begin{array}{l}\text { University of } \\
\text { Jyväskylä }\end{array}$ & Nordic & 2 & Explicit & Implicit \\
\hline $\begin{array}{l}\text { University of } \\
\text { Troms } \varnothing\end{array}$ & Nordic & 2 & No & Implicit \\
\hline $\begin{array}{l}\text { Linnaeus } \\
\text { University }\end{array}$ & Nordic & 3 & No & No \\
\hline $\begin{array}{l}\text { University of } \\
\text { Luleå }\end{array}$ & Nordic & 3 & No & Implicit \\
\hline Malmö University & Nordic & 3 & No & Implicit \\
\hline $\begin{array}{l}\text { Technical } \\
\text { University } \\
\text { Munich }\end{array}$ & Germany & 1 & Explicit & Implicit \\
\hline LMU Munich & Germany & 1 & No & No \\
\hline $\begin{array}{l}\text { Heidelberg } \\
\text { University }\end{array}$ & Germany & 1 & Implicit & No \\
\hline $\begin{array}{l}\text { Friedrich Schiller } \\
\text { University Jena }\end{array}$ & Germany & 2 & Explicit & Implicit \\
\hline $\begin{array}{l}\text { University of } \\
\text { Duisburg-Essen }\end{array}$ & Germany & 2 & No & Explicit \\
\hline
\end{tabular}


Table 11.2 (continued)

\begin{tabular}{l|l|l|l|l}
\hline & $\begin{array}{l}\text { Country } \\
\text { Block }\end{array}$ & $\begin{array}{l}\text { Performance } \\
\text { Group }\end{array}$ & $\begin{array}{l}\text { Reference to global } \\
\text { rankings 2014 (No/ } \\
\text { Implicit/Explicit) }\end{array}$ & $\begin{array}{l}\text { Reference to global } \\
\text { rankings 2018 (No/ } \\
\text { Implicit/Explicit) }\end{array}$ \\
\hline $\begin{array}{l}\text { University of } \\
\text { Hannover }\end{array}$ & Germany & 2 & No & No \\
\hline $\begin{array}{l}\text { Saarland } \\
\text { University }\end{array}$ & Germany & 3 & No & No \\
\hline $\begin{array}{l}\text { Technical } \\
\text { University } \\
\text { Dortmund }\end{array}$ & Germany & 3 & No & Implicit \\
\hline $\begin{array}{l}\text { University of } \\
\text { Kassel }\end{array}$ & Germany & 3 & No & No \\
\hline
\end{tabular}

have changed from implicit references to explicit ones: Uppsala University and University of Surrey. In 2018, many institutions that previous made no reference to the global rankings are now doing it implicitly, for example, the University of Lulea (now listed 801-900 by ARWU), Malmö University (not listed) and Technical University of Dortmund (now listed 501-600 by ARWU).

In short, the global rankings game may still be reserved first and foremost for the few hundred privileged institutions. The discourse of global excellence has become a common element of HEI strategies and the imaginary of competition now concerns institutions of all ranks. The references to global rankings have increased over time, and now involve institutions that do not rank or just barely do so. At the same time, the references to rankings have become more implicit in nature. This shows the difficulty of setting one's goals against them, and perhaps also increasing the awareness of their problems, as discussed below.

\section{Perceptions of University Rankings and Institutional Outlook}

Concerning general attitudes towards rankings, we had an initial impression, based largely on a non-systematic reading of institutions' webpage reactions to rankings, that the way rankings are presented (their premises, methodologies, origins) would be tactically oriented. We expected to find a measure of selectivity where the rankings are played down if they show one's institution in an unfavorable light, and celebrated if they show awarding or agreeable scores. More specifically, we were curious to see if there was resistance towards the whole rankings culture, most likely stemming from the unlisted institutions.

The references to ranking results in the institutional strategies generally differed from the institutions' webpage commentaries. Strategies were not used as reactivetactical platforms: they did not include disapproving remarks about individual rankings or ranking practice in general. In 2014, none of the 16 institutional strategies 
that mentioned rankings suggested negative connotations. Thus, evaluative remarks, where present, were rather mundane. They included:

1. positive celebrations of good ranking results (Nottingham, Central Lancashire, TUM)

2. reinforcement of rankings culture: rankings were taken seriously and targets were sometimes set in terms of them.

All in all, national and/or international rankings are present in most of the strategies analyzed. They were treated neutrally, and the impression given was that the scores they produce are credible representations of reality. Only seven of our cases did not include rankings discourse at all, four of them being Nordic. Strategies that ignored (were silent on) rankings altogether could signal negative attitudes or even resistance, but our data is insufficient to lend any meaningful support to such an interpretation.

In 2018, Universität Duisburg Essen shows reflexive insight about the rankings and the possibility of ignoring them. While the strategy first refers to improving the standing of the institution as a sign of improving research excellence (Universität Duisburg Essen 2015, p. 7 and p. 12), there is a full paragraph on the limitations of the rankings: that they overlook complexity and the diversity of their object of measurement, but that due to their effects, the university "cannot afford" to ignore (Universität Duisburg Essen 2015, p. 12). ${ }^{5}$ This shows the increasing awareness of the problems related to the rankings. While the universities would like to bow out of the ranking game, their field of activity is already governed through competitive imaginaries that are strongly related to the rankings. The institutions are hence compelled to position themselves vis-à-vis the ranking discourse, while (increasingly) acknowledging its pitfalls.

It was not as common to set clear targets according to ranking results in institutional strategies as we anticipated: still, in 2014, around one third of our sample institutions had done so. In eight strategy papers, objectives were set in terms of international league tables, in 11 the reference rankings were national. More than half of the universities, 15, did not imply that ranking positions had a direct role in their strategic target setting. Moreover, only five of those eight who proclaimed their objectives according to global tables specified the explicit ranking position they were aiming at, and only one of these was an unlisted institution according to the Shanghai list.

\footnotetext{
5 "Globale Hochschulrankings markieren durchaus sinnvoll Positionen, suggerieren aber auch die Vergleichbarkeit aller Universitäten weltweit, denn sie reduzieren die Universität und ihre Mitglieder in Forschung, Lehre und Verwaltung auf wenige, leicht handhabbare Parameter. Der Komplexität und Diversität einer Universität wird durch die Platzierung in Rankings zwar nicht Rechnung getragen, doch für die internationale Sichtbarkeit und für die Wahl einer Universität durch Studierende oder Wissenschaftlerinnen und Wissenschaftler kommt der Rankingposition eine immer größere Bedeutung zu. Insofern wird die UDE es sich nicht leisten können, die normative Wirkung von Rankings zu ignorieren." (Universität Duisburg Essen 2015, p. 12.)
} 
Table 11.3 HEIs with explicit references to rankings in their goal-setting in 2012 and their rankings in 2012 and 2018

\begin{tabular}{|c|c|c|c|}
\hline Institution & $\begin{array}{l}\text { Ranking position } \\
2012\end{array}$ & Target position & Ranking in 2018 \\
\hline University of Nottingham & 86 (ARWU) & Top-50 (ARWU) & 101-150 (ARWU) \\
\hline University of Liverpool & 101-150 (ARWU) & Top-75 (ARWU) & 101-150 (ARWU) \\
\hline $\begin{array}{l}\text { University of Eastern } \\
\text { Finland }\end{array}$ & $\begin{array}{l}302(\mathrm{QS}), 401-500 \\
\text { (ARWU) }\end{array}$ & $\begin{array}{l}\text { Top-200 (not } \\
\text { specified) }\end{array}$ & 401-500 (ARWU) \\
\hline $\begin{array}{l}\text { Friedrich Schiller } \\
\text { University Jena }\end{array}$ & 401-500 (ARWU) & Top-200 (ARWU) & 301-400 (ARWU) \\
\hline $\begin{array}{l}\text { University of Central } \\
\text { Lancashire }\end{array}$ & $\begin{array}{l}\text { 601+ (QS), unlisted } \\
\text { (ARWU) }\end{array}$ & Top-500 (QS) & $\begin{array}{l}\text { 801-1000 (QS), unlisted } \\
\text { (ARWU) }\end{array}$ \\
\hline
\end{tabular}

Table 11.3 shows the difficulty that the universities face when tying their strategic goals directly to university rankings. Of the five universities that had done this, only the Friedrich Schiller University Jena had been able to improve its position in the Shanghai list, though failing to reach its target position set in 2014. In short, none of the universities in question were able to reach their target goal set in 2014. This shows the difficulty of improving one's position in the rankings as well as the ambiguity of it as an explicit strategic goal.

There were also less explicit references to rankings as strategic goals, as the examples below show:

\begin{abstract}
University of Birmingham: "We have identified five key strategic goals, which will enable us to take our place as a leading global university. [...] success in all of these goals will require a step change in our performance, and this will be reflected by a rise in our position in the national and global league tables." (University of Birmingham 2010, p. 8)
\end{abstract}

Stockholm University: "Delmål: Universitetets placering på de främsta internationella rankinglistorna (Shanghai, Times) ska förbättras.” (Stockholm University 2009, p. 19)

University of Jyväskylä: "The University's position among the top 3 per cent in the global university rankings will show a continuous rise.” (University of Jyväskylä 2010, p. 3)

In terms of country blocks, there was some variation. Most evidently, with Surrey as the sole exception, all the British universities expressed their objectives in reference to national rankings in 2014. In the Nordic universities and in Germany, targeting by national rankings was rather exceptional. If it was generally accepted that institutional performance needs to be improved, it was uncommon to present one's achievement or desired future achievement in terms of ranking results. There were also differences among the three tiers of institutions. In 2014, only one of the lowest tier universities included performance target in terms of global rankings, and one can surmise that even this was because the institution in question, University of Central Lancashire, had made some headway on an alternative global league table (QS) and, strictly speaking, was not "unlisted" in an absolute sense. International rankings may not have such influence on the less prestigious institutions, but the game is still reserved for those who make it to the tables. 
While we do not find as broad enthusiasm to think in terms of rankings as Hazelkorn (2011, p. 86 and p. 93), it cannot be said that league tables (national and international) had merely imposed "changes to strategies or policies" (Locke et al. 2008 , p. 33). But the willingness to play the ranking game seems to be related to the relative status of the university. Our results suggest that enthusiasm to embed international rankings into strategic work is rather weak, particularly in lower-tier universities, which form the majority of the academic world. Nevertheless, it is significant that the global rankings have found their way to many of the "high" and "average" performing universities strategies, even if only implicitly. Such 'selectivity' may highlight the communicative function of the strategy documents: institutions' reference global rankings only if they help to create a positive image.

Comparing the references to rankings in 2012 and 2018, the references to the rankings become more implicit over time. This probably indicates better knowledge of rankings - what is measured - and how difficult it is to game them. At the same time, the underlying rationalities of the rankings and global higher education are inherently present in the language of HEI strategies. The language indicates an imaginary of global competition, where the universities are primarily competing over talented researchers, indicating a tendency toward individualization (Erkkilä and Piironen 2015), where the academic performance of institutions is reduced to individual researchers rather than a research collective or organizational culture.

\section{World-Class or Regional University? International Excellence and Regional Needs}

As the above discussion highlights, the global university rankings function as a mechanism of inclusion and exclusion for institutions to credibly participate in the pursuit for world-class higher education. But the marker does not seem to lie on the threshold of being ranked, but rather on the already top-100 positions. This indicates the persistence of the policy problem of European Higher Education and its framing: the focus on the top-100 institutions. This becomes particularly visible in the HEIs positioning on their global vs. regional role. In our sample of institutional strategies, 'excellence' was predominantly constructed on global models and benchmarks. As if to compensate this, there were also references to the regional role of the university, catering to local needs particularly present in the strategies of institutions under the top- 100 .

Though the direct references to rankings might be getting less explicit, there is nevertheless reflection on the global competition for 'excellence' in higher education-the world-class. In the Nordic block, for example, Stockholm University states that "the University's international status, as reflected in rankings and bibliometric surveys, should be monitored and followed up." (Stockholm University 2015 , 9). Uppsala University refers to systematic quality assessment through "international comparisons" and aims to strengthen its position as a "leading international 
research university" (Uppsala University 2014, p. 4 and p. 9). Malmö University aims for "internationally outstanding research", without specifying how this is to be assessed (Malmö University 2017, p. 4).

There are also more abstract references to world-class: Lund University refers to a world-class university "that works to understand, explain and improve our world and the human condition" (Lund University 2017, p. 4). Uppsala and Birmingham both refer to "world-leading research" (Uppsala University 2014, p. 4; University of Birmingham 2015, p. 4). The University of Troms $\varnothing$ aims to be "a research-driven university with researchers and research groups that are innovative and at the international research frontier in their fields." (University of Troms $\varnothing$ 2014). A similar claim is presented in the strategy of the University of Jyväskylä (Jyväskylän yliopisto 2014, p. 2).

We initially spotted some references to the regional role of the universities in the 2014 sample and, in 2018, there are explicit references to regionalism. This is often seen as a complement to the universities' international role. The international rankings seem to set the boundaries within which the universities imagine themselves as being part of a global higher education. Excellence is something that is constructed and assessed against international benchmarks, but there are also 'regional needs' to which the universities must attend. For example, the University of Anglia Ruskin claims to "focus our investment in people, infrastructure and our research institutes in key areas of international excellence and regional need, delivering research and innovation of outstanding quality and impact[...]" (Anglia Ruskin University 2017, p. 3 , italics added).

As Table 11.4 below shows, the regional focus was particularly visible in the strategies of universities that do not rank (group 3) or just barely do so (group 2), while the institutions that are able to compete credibly for top-100 positions globally (group 1) do not have a strong regional focus, except for the University of Birmingham. In general, the regional focus of the universities is highlighted in the UK context, where six of the nine universities have a strong emphasis on their regional role in their strategies. The remaining three UK universities, two of which are in the ARWU 101-150 category, also mention the regional aspect. Even the German universities mostly referred to a regional role of some sort, while there were differences in the references. The Nordic universities stand out to some extent, as there are institutions in all performance groups that do nor refer to their regional role at all. This does not mean that there is no regional role, however. For example, the Finnish higher education system has got a strong regional focus. But having a regional role does not mean that one has to exclaim it. On the contrary, it seems that the discourse of regional role reflects the world-class discourse, rather than a candid self-assessment of one's regional priorities.

There is a clear tendency for the universities that are globally ranked in top- 100 or just below (group 1) not to stress their regional role, but instead to engage in the struggle for 'world-class' status. But moving down the rankings (groups 2 and 3) the strong regional role becomes explicit. We see this as a reflection on the global model of higher education, where the universities are considered "responsible to society" (see above) in terms of their contribution to economic development, but at the same time evaluated against the global blueprint of world-class university. As 
Table 11.4 References to university's regional role in HEI strategies (2018)

\begin{tabular}{|c|c|c|c|c|}
\hline & Institution & $\begin{array}{l}\text { Strong regional } \\
\text { role }\end{array}$ & $\begin{array}{l}\text { Regional role } \\
\text { mentioned }\end{array}$ & $\begin{array}{l}\text { Regional role not } \\
\text { mentioned }\end{array}$ \\
\hline \multirow[t]{9}{*}{ Group 1} & University of Nottingham & & $\mathrm{x}$ & \\
\hline & $\begin{array}{l}\text { University of } \\
\text { Birmingham }\end{array}$ & $\mathrm{x}$ & & \\
\hline & University of Liverpool & & $\mathrm{x}$ & \\
\hline & $\begin{array}{l}\text { Technical University } \\
\text { Munich }\end{array}$ & & & $\mathrm{x}$ \\
\hline & LMU Munich & & $\mathrm{x}$ & \\
\hline & Heidelberg University & & $\mathrm{x}$ & \\
\hline & $\begin{array}{l}\text { Uppsala University } \\
\text { (SWE) }\end{array}$ & & $\mathrm{x}$ & \\
\hline & $\begin{array}{l}\text { Stockholm University } \\
\text { (SWE) }\end{array}$ & & & $\mathrm{x}$ \\
\hline & Lund University (SWE) & & & $\mathrm{x}$ \\
\hline \multirow[t]{9}{*}{ Group 2} & University of Essex & & $\mathrm{x}$ & \\
\hline & University of Surrey & $\mathrm{x}$ & & \\
\hline & Swansea University & $\mathrm{x}$ & & \\
\hline & $\begin{array}{l}\text { Friedrich Schiller } \\
\text { University Jena }\end{array}$ & & $\mathrm{x}$ & \\
\hline & $\begin{array}{l}\text { University of } \\
\text { Duisburg-Essen }\end{array}$ & $\mathrm{x}$ & & \\
\hline & University of Hannover & $\mathrm{x}$ & & \\
\hline & $\begin{array}{l}\text { University of Eastern } \\
\text { Finland }\end{array}$ & & & $\mathrm{x}$ \\
\hline & $\begin{array}{l}\text { University of Jyväskylä } \\
\text { (FI) }\end{array}$ & & & $\mathrm{x}$ \\
\hline & $\begin{array}{l}\text { University of Troms } \emptyset \\
\text { (NOR) }\end{array}$ & $\mathrm{x}$ & & \\
\hline \multirow[t]{9}{*}{ Group 3} & Anglia Ruskin & $\mathrm{x}$ & & \\
\hline & Sheffield Hallam & $\mathrm{x}$ & & \\
\hline & Central Lancashire & $\mathrm{x}$ & & \\
\hline & Saarland University & $\mathrm{x}$ & & \\
\hline & $\begin{array}{l}\text { Technical University } \\
\text { Dortmund }\end{array}$ & $\mathrm{x}$ & & \\
\hline & University of Kassel & $\mathrm{x}$ & & \\
\hline & $\begin{array}{l}\text { Linnaeus University } \\
\text { (SWE) }\end{array}$ & $\mathrm{x}$ & & \\
\hline & $\begin{array}{l}\text { University of Luleå } \\
\text { (SWE) }\end{array}$ & & $\mathrm{x}$ & \\
\hline & $\begin{array}{l}\text { Malmö University } \\
\text { (SWE) }\end{array}$ & & & $\mathrm{x}$ \\
\hline
\end{tabular}


the non-ranking institutions fail to do the latter, their logical strategy is to highlight the former - they might not be 'world-class', but still major players in their regional context.

The descriptions of the regional role nevertheless draw on the imaginary of global competition. The universities are described as innovation hubs, sources of an educated work force and beacons of the region to the world outside also competing for talent. But the discussion of the regional context differs strongly in the different groups of institutions. In the top-ranking group of our assessment, the LMU Munich presents the city surrounding it as an exciting urban environment that its students and researchers can enjoy. In other words, the city is there for the university. The only institution in the highest performance group to have a strong emphasis on its regional role, the University of Birmingham, sees itself in a balanced relationship with its surrounding region, profiting from it but also giving back:

The University of Birmingham is rooted in a youthful, diverse and vibrant region. The Midlands is the engine of British manufacturing and export and a magnet for innovation, entrepreneurship, arts, culture, business, science, and technology. At the University we bring together the people and resources to tackle the major challenges of our time, including health and well-being, economic revitalisation, energy and sustainability, climate change, and inter-faith understanding. We draw on and give back to the region through our research, our educational offerings, and our global reach and reputation. (University of Birmingham 2015, p. 2)

In the group of universities that do not rank, the institutions perceive themselves more as contributing to the region than as profiting from it. For example, the University of Saarland presents its regional role almost as its reason to exist, profiling itself as the "innovation centrum" of the region (Universität des Saarlandes 2013, p. 7). ${ }^{6}$ University of Troms $\varnothing$ and the University of Central Lancashire both describe themselves as responsible regional actors that are nevertheless internationally connected:

UiT contributes to knowledge-based development at the regional, national and international level. Our central location in the High North, our broad and diverse research and study portfolio, our geographical breadth and our interdisciplinary qualities make us uniquely suited to meet the challenges of the future. (University of Tromso 2014)

UiT will help promote economic, cultural and social development in the north through building knowledge and human capital. (University of Tromso 2014

UiT will strengthen its position and its reputation through good communication, dissemination of its work and a clear profile. UiT will be a driving force for increased innovation and business development in the High North. (University of Tromso 2014)

Whilst international in reach and outlook, UCLan proudly retains its roots in the City of Preston and the region. [...] Preston campus will transform the University as a place to

\footnotetext{
6"Die Universität betrachtet eine an wissenschaftlichen und professionellen Standards orientierte Ausbildung als eine ihrer Kernaufgaben. Darüber hinaus übernimmt sie tragende Aufgaben als Innovationszentrum des Landes[...]" (Universität des Saarlandes 2013, p. 7).
} 
learn, work and do business; whilst UCLan's commitment to high quality academic provision will be further strengthened by our prestigious undergraduate medical degree and expansion of our engineering delivery to help meet the growing demands of regional employers. (University of Central Lancashire 2015, p. 2)

The University will be innovative and entrepreneurial in our approach to research and knowledge exchange in order to maximise our positive social, environmental and economic impact locally, nationally and globally. (University of Central Lancashire 2015, p. 3)

Deep-rooted engagement between our University and the wider communities of Preston, Lancashire and the North West, encouraging the sharing of ideas, knowledge and the spark of learning. (University of Central Lancashire 2015, p. 12)

Here the universities portray themselves as engines of innovation in their given region, primarily responsible to society in economic terms, as depicted by the European Commission. This also echoes the global policy script for higher education and innovation, where the focus is shifting to regional level-local innovation (Erkkilä and Piironen 2018). But while the major research universities certainly have a great impact on their regions, the less prominent institutions now ride on this discourse. Though the regional role of these universities could be an alternative to the discourse of 'world-class', it seems rather to be a reflection of it.

Indeed, the organizational and financial autonomization of higher education institutions has led to increased use of a variety of ex post accountability mechanisms in Europe (Boer et al. 2010; also Erkkilä and Piironen 2013b), now also including the international league tables that order academic institutions according to a single aggregate score. Consequently, benchmarking against similar units nationally and internationally has followed. But only a fraction of universities can credibly claim to be part of the global competition for excellence, and the focus on top-100 positions in the European context makes the mark even more exclusive.

In fact, a position in the top-100 now appears to be a watershed for the European universities in our sample: the institutions within or just below this ranking (ARWU 50-150) perceive themselves as comfortably situated in the global model of a world-class university. The institutions ranked clearly beneath this mark (401-500) or unlisted are compelled to frame themselves differently, emphasizing instead their regional role. This is not a true alternative to the 'world-class' model, but rather an instance of the discourse on global higher education, where the notion of regional university appears as a pattern of identity that is acquired and constructed vis-à-vis the world-class 'other'.

\section{Conclusions}

Global university rankings have had a fundamental effect on higher education policies and institutional strategies. They have helped to construct a global model of excellence, the world-class university, that is now reflected on different levels of higher education governance. In Europe, the global rankings have been used to 
construct a policy problem of 'European higher education', helping the EU Commission become a player in a policy field that is outside its official competencies. The focus on institutions in the top-100 of the prominent rankings in the framing of the policy problem is particularly interesting. It demonstrates an advantage for the North American institutions, but overlooks the fact that there are significantly more European institutions among those ranked overall.

The global ranking game draws attention to individual institutions instead of national higher education systems. This individualization is likely to be counterproductive for national systems that now lack orientation and mounts pressure for strategic reorientation of academic institutions, though most of them have no realistic means to attain a significant position in the global rankings to begin with. Looking at the institutional strategies of European HEIs, several institutions in our sample did express their targets in terms of global ranking positions, indicating an imaginary of global competition, which would have been unthinkable only 20 years ago, and highly unlikely even only a decade ago.

The references to rankings have been downplayed over time, becoming more implicit. But the language of competition and benchmarking is now omnipresent in the institutional strategies analyzed and becoming more commonplace. Excellence is strongly related to the international sphere-the world class model. In principle, this concerns all higher education institutions, but the global rankings function here as a mechanism of inclusion and exclusion, where institutions in the top-100 or just below it can claim to be in the race.

But the global model of higher education now also concerns those institutions that are seemingly excluded from it. We observe a clear trend for claiming regional importance, particularly among those institutions that are below the top-100, the bar set by the European Commission. However, in our analysis, the regional focus does not appear to be a viable alternative to the 'world class university', but rather reflects this global discourse.

\section{References}

Anglia Ruskin University. (2017). Designing our future 2017-2026. https://www.anglia.ac.uk/-/ media/Files/corporate-documents/designing-our-future-2017-2026.pdf?la=en \&hash=63C85 9F8A3042ED21DB537268598594F. Accessed 11 Jan 2019.

Bacchi, C. L. (1999). Women, policy and politics: The construction of policy problems. London: Sage Publications.

Cheng, Y., \& Liu, N. C. (2006). A first approach to the classification of the top 500 world universities by their disciplinary characteristics using scientometrics. Scientometrics, 68(1), 135-150.

Cheng, Y., \& Liu, N. C. (2007). Academic ranking of world universities by broad subject fields. Higher Education in Europe, 32(1), 17-29.

Cohen, A. M., \& Kisker, C. B. (2010). The shaping of American higher education: Emergence and growth of the contemporary system. San Francisco: Jossey-Bass.

Dakowska, D. (2013). Polish higher education and the global academic competition: University rankings in the reform debates. In T. Erkkilä (Ed.), Global university rankings. Challenges for European higher education (pp. 107-123). Basingstoke: Palgrave Macmillan. 
de Boer, H., Jongbloed, B., Enders, J., \& File, J. (2010). Progress in higher education reform across Europe. Governance reform. Volume 1: Executive summary main report. Center for Higher Education Policy Studies, University of Twente.

de Ridder-Symoens, H. (Ed.). (2003a). A history of the university in Europe: Volume 1, universities in the middle ages: Universities in the middle ages vol 1. Cambridge: Cambridge University Press.

de Ridder-Symoens, H. (Ed.). (2003b). A history of the university in Europe: Volume 2, universities in early modern Europe (1500-1800): Universities in early modern Europe (1500-1800) vol 2. Cambridge: Cambridge University Press.

Deem, R., Mok, K. H., \& Lucas, L. (2008). Transforming higher education in whose image? Exploring the concept of the 'world-class' University in Europe and Asia. Higher Education Policy, 21(1), 83-97.

Dehon, C., McCathie, A., \& Verardi, V. (2009a). Uncovering excellence in academic rankings: A closer look at the Shanghai ranking. Scientometrics, 83(2), 515-524.

Dehon, C., Vermandele, C., \& Jacobs, D. (Eds.). (2009b). Ranking universities. Brussels: Université de Bruxelles.

DiMaggio, P. J., \& Powell, W. W. (1983). The iron cage revisited: Institutional isomorphism and collective rationality in organizational fields. American Sociological Review, 48(2), 147-160.

Erkkilä, T. (Ed.). (2013). Global university rankings: Challenges for European higher education. Houndmills: Palgrave Macmillan.

Erkkilä, T. (2016). Global university rankings and transnational politics of higher education. In M. H. Chou, I. Kamola, \& T. Pietsch (Eds.), The transnational politics of higher education: Contesting the global/transforming the local (pp. 178-196). New York: Routledge.

Erkkilä, T., \& Piironen, O. (2009). Politics and numbers: The iron cage of governance indices. In R. W. Cox III (Ed.), Ethics and integrity in public administration: Concepts and cases (pp. 125-145). Armonk: M.E. Sharpe.

Erkkilä, T., \& Piironen, O. (2013a). Reforming higher education institutions in Finland: Competitiveness and global university rankings. In T. Erkkilä (Ed.), Global university rankings: Challenges for European higher education. Houndmills: Palgrave Macmillan.

Erkkilä, T., \& Piironen, O. (2013b). Shifting fundaments of European higher education governance: Competition, ranking, autonomy and accountability. Comparative Education, online before print, https://doi.org/10.1080/03050068.2013.807643.

Erkkilä, T., \& Piironen, O. (2015). Autonomisation and individualisation: Ideational shifts in European higher education. In J. Nixon \& L. Evans (Eds.), Academic identities and the changing European landscape (pp. 47-62). London: Bloomsbury.

Erkkilä, T., \& Piironen, O. (2018). Rankings and global knowledge governance: Higher education, innovation and competitiveness. New York: Palgrave Macmillan.

European Commission. (2005a). Annex to the Communication from the commission. Mobilising the brainpower of Europe: Enabling universities to make their full contribution to the Lisbon Strategy. European higher education in a worldwide perspective, SEC(2005) 518. Brussels: European Commission.

European Commission. (2005b). Mobilising the brainpower of Europe: Enabling universities to make their full contribution to the Lisbon Strategy, COM(2005) 152 final. Brussels: European Commission.

European Commission. (2006). Europe needs modernised universities, says European Commission, press release, IP/06/592. Brussels: European Commission.

European Commission. (2008). Commission staff working document. Accompanying document to the report from the commission to the council on the council resolution of 23 November 2007 on modernising universities for Europe's competitiveness in a global knowledge economy'. SEC(2008) 2719. Brussels: European Commission.

European Commission. (2009). Commission staff working document. In Progress towards the Lisbon objectives in education and training: Indicators and benchmarks 2009', SEC(2009) 1616. Brussels: European Commission. 
European Commission. (2011). Supporting growth and jobs - an agenda for the modernisation of Europe's higher education system, COM(2011) 567 final. Brussels: European Commission.

Gornitzka, A. (2013). Channel, filter or buffer? National policy responses to global rankings. In T. Erkkilä (Ed.), Global university rankings: Challenges for European higher education (pp. 75-91). Houndmills: Palgrave Macmillan.

Hazelkorn, E. (2007). The impact of league tables and ranking systems on higher education decision making. Higher Education Management and Policy, 19(2), 87-110.

Hazelkorn, E. (2008). Learning to live with league tables and ranking: The experience of institutional leaders. Higher Education Policy, 21(2), 193-215.

Hazelkorn, E. (2009). Rankings and the battle for world-class excellence: Institutional strategies and policy choices. Higher Education Management and Policy, 21(1), 1-22.

Hazelkorn, E. (2011). Rankings and the reshaping of higher education: The battle for world-class excellence. Basingstoke/New York: Palgrave Macmillan.

Hughes, O. E. (2003). Public management and administration: An introduction (3rd ed.). Houndmills: Palgrave Macmillan.

Jyväskylän yliopisto. (2014). Jyväskylän Yliopiston Strategia 2015-2020. https://www.jyu.fi/hallinto/strategia/strategiat/strategia. Accessed 11 Jan 2019.

Kauppi, N. (2013). Ranking European social sciences and stratifying global knowledge: The example of European political science. In T. Erkkilä (Ed.), Global university rankings: Challenges for European higher education (pp. 20-35). Houndmills: Palgrave Macmillan.

Kehm, B. (2013). The impact of rankings on the European higher education landscape. In T. Erkkilä (Ed.), Global university rankings: Challenges for European higher education (pp. 20-35). Houndmills: Palgrave Macmillan.

Kehm, B. M., \& Stensaker, B. (2009). University rankings, diversity, and the new landscape of higher education. Leiden: Brill Sense.

King, R. (2010). Governing universities globally: Organizations, regulation and rankings. Reprint. Celtenham: Edward Elgar Publishing Ltd.

Locke, W. (2011). The institutionalization of rankings: Managing status anxiety in an increasingly marketized environment. In J. C. Shin, R. K. Toutkoushian, \& U. Teichler (Eds.), University rankings: Theoretical basis, methodology and impacts on global higher education (pp. 201-228). Dordrecht: Springer.

Locke, W., et al. (2008). Counting what is measured or measuring what counts? League tables and their impact on higher education institutions in England (report to HEFCE). Bristol: Higher Education Funding Council for England.

Lund University. (2017). Strategic plan 2017-2026. https://www.lunduniversity.lu.se/sites/www. lunduniversity.lu.se/files/strategic_plan_2017-2026updated030517.pdf. Accessed 11 Jan 2019.

Malmö University. (2017). Malmö University Strategy 2022. https://mau.se/contentassets/1 ab15f0183324e8fb3a261dcf2510486/malmo-university-strategy-2022_eng_original.pdf. Accessed 14 Jan 2019.

Marginson, S., \& van der Wende, M. (2007). To rank or to be ranked: The impact of global rankings in higher education. Journal of Studies in International Education, 11(3-4), 306-329.

Miller, P., \& Rose, N. (1990). Political rationalities and technologies of hovernment. In S. Hänninen \& K. Palonen, Texts, Contexts, Concepts. Studies on Politics and Power in Language (pp. 166-83). Helsinki: The Finnish Political Science Association

Mok, K. H. (2007). Globalisation, new education governance and state capacity in East Asia. Globalisation, Societies \& Education, 5(1), 1-21.

Morphew, C. C., \& Swanson, C. (2011). On the efficacy of raising your university's rankings. In J. C. Shin, R. K. Toutkoushian, \& U. Teichler (Eds.), University rankings: Theoretical basis, methodology and impacts on global higher education (pp. 185-199). Dordrecht: Springer.

Münch, R. (2013). The colonization of the academic field by rankings: Restricting diversity and obstructing the progress of knowledge. In T. Erkkilä (Ed.), Global university rankings: Challenges for European higher education (pp. 196-221). Houndmills: Palgrave Macmillan. 
Nixon, J. (2013). The drift to conformity: The myth of institutional diversity. In T. Erkkilä (Ed.), Global university rankings: Challenges for European higher education (pp. 92-106). Houndmills: Palgrave Macmillan.

Olsen, J. P., \& Maassen, P. (2007). European debated on the knowledge institution: The modernization of the university at the European level. In P. Maassen \& J. P. Olsen (Eds.), University dynamics and European integration (pp. 3-23). Dordrecht: Springer.

Pelkonen, A., \& Teräväinen-Litardo, T. (2013). Convergence and divergence in research, higher education and innovation policies: An analysis of nine European countries. In T. Erkkilä (Ed.), Global university rankings: Challenges for European higher education (pp. 53-74). Houndmills: Palgrave Macmillan.

Reinalda, B., \& Kulesza, E. (2006). The Bologna process: Harmonizing Europe's higher education. In Opladen. Farmington Hills: Budrich.

Rüegg, W. (Ed.). (2004). A history of the University in Europe: Volume 3, universities in the nineteenth and early twentieth centuries (1800-1945): Universities in the early twentieth centuries (1800-1945) Vol 3. Cambridge: Cambridge University Press.

Rüegg, W. (Ed.). (2010). A history of the university in Europe: Volume 4, universities since 1945. Cambridge: Cambridge University Press.

Salmi, J. (2009). The challenge of establishing world-class universities. Washington, DC: World Bank.

Schmidt, V. A. (2006). Democracy in Europe: The EU and national polities. Oxford: Oxford University Press.

Schmidt, V. A. (2010). Taking ideas and discourse seriously: Explaining change through discursive institutionalism as the fourth "new institutionalism". European Political Science Review, 2(1), 1-25.

Schofer, E., \& Meyer, J. W. (2005). The worldwide expansion of higher education in the twentieth century. American Sociological Review, 70(6), 898-920.

Shin, J. C., \& Kehm, B. M. (Eds.). (2012). Institutionalization of world-class university in global competition (2013th ed.). Dordrecht: Springer.

Shin, J. C., Toutkoushian, R. K., \& Teichler, U. (Eds.). (2011). University rankings: Theoretical basis, methodology and impacts on global higher education. Dordrecht: Springer.

Stockholm University. (2009). Långsiktig plan 2010-2014. http://www.su.se/polopoly_ fs/1.3197.1320939303!/Langsiktiga\%20plan.pdf. Accessed 11 Jan 2019.

Stockholm University. (2015). Strategies for Stockholm University 2015-2018. https://www.su.se/ polopoly_fs/1.220898.1496237800!/menu/standard/file/Strategies.pdf. Accessed 11 Jan 2019.

Teichler, U. (2011). Social contexts and systemic consequence of university rankings: A metaanalysis of the ranking literature. In J. C. Shin, R. K. Toutkoushian, \& U. Teichler (Eds.), University rankings: Theoretical basis, methodology and impacts on global higher education (pp. 55-69). Dordrecht: Springer.

Universität des Saarlandes. (2013). Fortschreibung Des Universitätsentwicklungsplans 2011-2013 Für Das Jahr 2014. https://www.uni-saarland.de/fileadmin/upload/universitaet/praesidium/ UEP_2014.pdf. Accessed Jan 2019.

Universität Duisburg Essen. (2015). Hochschulentwicklungsplan 2016-2020.. https://www.unidue.de/imperia/md/content/webredaktion/2016/hochschulentwicklungsplan_2016-20.pdf. Accessed Jan 2019.

University of Birmingham. (2010). Shaping our future: Birmingham 2015. https://www.birmingham.ac.uk/Documents/university/shaping-future.pdf. Accessed Feb 2020.

University of Birmingham. (2015). Strategic framework 2015-2020. https://www.birmingham. ac.uk/Documents/strategic-framework/strategic-framework-2015-2020.pdf. Accessed 11 Jan 2019.

University of Central Lancashire. (2015). Strategy 2015-2020. https://www.uclan.ac.uk/research/ environment/assets/UCLan_STRATEGY_DOCUMENT.pdf. Accessed 11 Jan 2019. 
University of Jyväskylä. (2010). Excellence and dynamism: University of Jyväskylä 2017. https:// docplayer.net/16379357-Excellence-and-dynamism-university-of-jyvaskyla-2017.html. Accessed Feb 2020.

University of Tromso. (2014). Strategic plan for UiT The Arctic University of Norway 2014-2022, UiT. 2014. https://en.uit.no/go/target/377752. Accessed 11 Jan 2019.

Uppsala University. (2014). Uppsala University: Mission and core values. http://regler.uu.se/ digitalAssets/14/c_14263-1_1-k_ufv2013-110_uppsala-university\%2D\%2D-mission-andcore-values\%2D\%2D1-.pdf. Accessed 11 Jan 2019.

Open Access This chapter is licensed under the terms of the Creative Commons Attribution 4.0 International License (http://creativecommons.org/licenses/by/4.0/), which permits use, sharing, adaptation, distribution and reproduction in any medium or format, as long as you give appropriate credit to the original author(s) and the source, provide a link to the Creative Commons license and indicate if changes were made.

The images or other third party material in this chapter are included in the chapter's Creative Commons license, unless indicated otherwise in a credit line to the material. If material is not included in the chapter's Creative Commons license and your intended use is not permitted by statutory regulation or exceeds the permitted use, you will need to obtain permission directly from the copyright holder. 